\title{
PENGARUH EKSTRAK DAUN MINDI (Melia azadirach) TERHADAP PENEKANAN PELETAKAN DAN PENETASAN TELUR ULAT HATI KUBIS (Crocidolomia pavonana F.)
}

\author{
Abdul Manan ${ }^{*}$ dan Endang Mugiastuti ${ }^{2}$ \\ ${ }^{1}$ Agroteknologi, Universitas Jenderal Soedirman, abdulmanan.unsoed@gmail.com \\ ${ }^{2}$ Agroteknologi, Universitas Jenderal Soedirman
}

INFO ARTIKEL

RiwayatArtikel:

Diterima: 01-07-2019

Disetujui: 11-08-2019

\section{Kata Kunci:}

Mindi

C. pavonana

Peletakan telur

Penetasan telur

\section{ABSTRAK}

\begin{abstract}
Abstrak: Penelitian ini bertujuan untuk mengetahui konsentrasi daun mindi yang efektif untuk menekan peletakan dan penetasan telur C. pavonana. Percobaan dilaksanakan di Laboraorium Perlindungan Tanaman Fakultas Pertanian Unsoed Purwokerto. Rancangan yang digunakan adalah Rancangan Acak Kelompok. Perlakuan yang dicoba adalah konsentrasi ekstrak daun mindi $0 \%, 2,5 \%, 5,0 \%, 7,5 \%$, dan 10\%. Pamameter yang diamati adalah jumlah kelompok telur yang diletakkan dan jumlah kelompok telur yang menetas. Hasil penelitian menunjukkan bahwa, ekstrak daun mindi 7-10\% mampu menekan 100,00\% peletakan telur, dan ekstrak daun mindi 10\% mampu menekan $90,92 \%$ penetasan telur.
\end{abstract}

\begin{abstract}
This research aims to determine the effective concentration of melia leaf extract in suppressing the eggs laying and egg haching of $C$. pavonana. This research was conducted at the Laboratory of Plant Protection Faculty of Agriculture Unsoed at Purwokerto. The design used was randomized block design. The treatments tested were concentration of melia leaf extract $0,2.5 \%, 5.0 \%, 7.5 \%$, and $10.0 \%$. The variables measured were the number of clusters of eggs laid and number of eggs that hatched. The results showed that melia leaf extract concentration of $7,5-10,0 \%$ was effective in suppressing the oviposition of C. pavonana amounted to $96,00 \%$ and concentration of $10 \%$ was effective in suppressing egg hatcing of C. pavonana of $90,9 \%$.
\end{abstract}

\section{A. LATAR BELAKANG}

Kubis (Brassica oleracea var. capitata) merupakan tanaman sayuran yang banyak disukai masyarakat Indonesia, karena rasanya yang renyah dan segar, serta banyak mengandung vitamin, mineral, serta serat. Disamping banyak digunakan sebagai bahan dalam masakan sehari-hari, saat ini senyawa aktif yang dikandung kubis banyak diteliti sebagai obat herbal. [1], [2], [3], dan [4] melaporkan senyawa glukosinolat dan senyawa hidrolisisnya seperti indol dan isotiosianat terbukti mengurangi resiko kanker dan beberapa penyakit lainnya.

Produksi kubis nasional masih tergolong rendah, pada tahun 2016 tercatat sebesar 1.513.326 ton, dan cenderung naik dari tahun ke tahun [5]. Permintaan sayuran ini dari tahun ke tahun semakin meningkat seiring dengan meningkatnya jumlah penduduk dan peningkatan tingkat kesejahteraan serta kesadaran gizi masyarakat.
Peningkatan produksi kubis nasional masih menghadapi banyak kendala. Salah satu kendala utamanya adalah serangan ulat krop kubis (Crocidolomia pavonana). Hama ini merusak tanaman kubis dari tanaman muda sampai hampir panen. Kehilangan hasil akibat serangan hama ini dapat mencapai 100 \% tertama pada musim kemarau [6]; [7]; [8]; [9].

Pengendalian C. pavonana oleh petani lebih ditekankan kepada penggunaan pestisida kimia sintetik. Namun demikian, telah diketahui penggunaan cara tersebut tidak ekonomis dan banyak menimbulkan dampak negatif terhadap lingkungan. Kerugian yang diakibatkan oleh cara tersebut mendorong perlunya dicari cara pengendalian efektif tetapi ramah lingkungan yaitu pemanfaatan pestisida nabati [10].

Tanaman mindi (Melia azederach) merupakan salah satu anggoa famili Meliaceae yang banyak 
digunakan sebagai bahan pestisida nabati [11]; [12]; [13]; [10] Biji yang sudah tua merupakan bagian tanaman yang biasa digunakan sebagai pestisida nabati karena kandungan senyawa aktifnya paling tinggi [14]. Namun demikian, penggunaan biji sebagai bahan pestisida nabati terkendala musim dan kelimpahannya yang sulit dicapai. Oleh karena itu, pemilihan daun mindi sebagai bahan pestisida nabati merupakan alternatif yang potensial. Disisi lain, upaya pengendalian hama di lapangan masih belum memuaskan, karena hama $C$. pavonana masuk kedalam krop kubis sehingga sulit dikendalikan. Oleh karena itu upaya pengendalian terhadap hama lebih ditekankan kepada upaya menggagalkan imago hama untuk meletakkan telur dan menekan penetasan telurnya sebelum larva masuk ke dalam krop. Namun demikian informasi mengenai konsentrasi yang efektif untuk menekan peletakan dan penetasan telur hama ini relatif kurang tersedia.

Penelitian ini bertujuan untuk mengetahui: konsentrasi ekstrak daun mindi yang efektif menekan peletakan dan penetasan telur C. Pavonana. Hasil penelitian ini dapat digunakan untuk menyusun strategi pengendalian hama C. pavonana secara efektif, efisien, dan ramah lingkungan serta melengkapi komponen Pengendalian hama terpadu yang sudah ada.

\section{B. METODE PENELITIAN}

Penelitian ini dilakukan di Laboratorium Perlindungan Tanaman Fakultas Pertanian Unsoed Purwokerto selama 4 (empat) bulan, dari bulan Januari sampai bulan April 2018. C. pavonana yang digunakan diperoleh dari pertanaman kubis di desa Serang Kecamatan Karangreja Kabupaten Purbalingga ( \pm 1100 $m$ dpl) yang kemudian dikembangbiakkan di Laboratorium. Daun mindi merupakan koleksi Laboratorium Perlintan Fakultas Pertanian Unsoed. Pengujian peletakan telur menggunakan sangkar kain kasa berukuran 100x40x40 cm; sedangkan pengujian penetasan telur menggunakan cawan petri diameter 12 $\mathrm{cm}$.

Penelitian ini dilaksaanakan dalam dua set percobaan. Percobaan pertama adalah uji kemampuan ekstrak daun mindi terhadap peletakan telur $C$. pavonana. Rancangan yang diguanakan adalah Rancangan Acak Kelompok. Perlakuan yang dicoba adalah: ekstrak daun mindi o\% (o g daun mindi/10o ml air), 2,5\% (2,5 g daun mindi/100 ml air), 5,0\% (5,0 g daun mindi/100 $\mathrm{ml}$ air), 7,5\% (7,5 g daun mindi/100 ml air), dan 10\% (10g daun mindi/100 ml air).

Daun kubis disemprot ekstrak daun mindi sesuai perlakuan dan dikeringanginkan. Selanjutnya dimasukkan ke dalam sangkar kain kasa yang berisi 200 pasang dewasa C. pavonana yang baru keluar dari pupa. Daun kubis diinkubasikan selama 24 jam, kemudian dihitung jumlah kelompok telur yang menempel pada daun kubis. Penelitian kedua adalah uji kemempanan ekstrak daun mindi terhadap penetasan telur $C$. pavonana. Rancangan yang digunakan adalah rancangan Rancangan Acak Kelompok. Perlakuan yang dicoba adalah konsentrasi ekstrak daun mindi $0 \%$, $2,5 \%, 5 \%, 7,5 \%$, dan $10 \%$. Lima kelompok telur $C$. pavonana disemprot ekstrak daun mindi sesuai perlakuan. Kelompok telur tersebut kemudian dimasukkan ke dalam cawan petri. Jumlah kelompok telur yang menetas selama 3, 4, 5, dan 6 hari setelah perlakuan kemudian diamati.

\section{HASIL DAN PEMBAHASAN}

\section{Uji kemempanan ekstrak daun mindi terhadap peletakan telur C. pavonana}

Jumlah kelompok telur yang diletakkan imago C. pavonana pada perlakuan konsentrasi daun mindi disajikan pada tabel 1. Kelompok telur terbanyak diletakkan pada perlakuan kontrol yaitu 15,o kelompok telur, sedangkan jumlah kelompok telur pada perlakuan ekstrak daun mindi pada berbagai konsentrasi lebih sedikit. Jumlah kelompok telur pada perlakuan ekstrak daun mindi 2,5\% mencapai 4,2 kelompok telur dan semakin turun seiring dengan meningkatnya konsentrasi, bahkan pada perlakuan ekstrak daun mindi 7,5 dan 10\% tidak ada kelompok telur yang diletakkan sama sekali (Tabel 1).

Tabel 1.

Jumlah kelompok telur C. pavonana yang diletakkan pada perlakuan konsentarsi ekstrak daun mindi

\begin{tabular}{|c|c|c|}
\hline Perlakuan & $\begin{array}{c}\text { Jumlah } \\
\text { kelompok telur } \\
\text { yang diletakkan }\end{array}$ & $\begin{array}{c}\text { Penekanan } \\
\text { peletakan telur } \\
(\%)\end{array}$ \\
\hline Kontrol & $15, \mathrm{O} \mathrm{d}$ & - \\
\hline $\begin{array}{l}\text { Ekstrak daun } \\
\text { mindi } 2,5 \%\end{array}$ & $4,2 \mathrm{~b}$ & 72 \\
\hline $\begin{array}{l}\text { Ekstrak daun } \\
\text { mindi 5,0 \% }\end{array}$ & $0,6 \mathrm{~b}$ & 96 \\
\hline $\begin{array}{l}\text { Ekstrak daun } \\
\text { mindi } 7,5 \%\end{array}$ & $0,0 \mathrm{a}$ & 100 \\
\hline $\begin{array}{l}\text { Ekstrak daun } \\
\text { mindi } 10,0 \%\end{array}$ & $0,0 \mathrm{a}$ & 100 \\
\hline
\end{tabular}

Hasil analisis statistik menunjukkan bahwa semua perlakuan ekstrak daun mindi berpengaruh nyata terhadap jumlah kelompok telur yang diletakkan dibandingkan dengan kontrol. Hal ini membuktikan ekstrak daun mindi mengandung senyawa kimia yang mempunyai efek antipeletakan telur terhadap imago C. pavonana. [15] melaporkan bahwa, mindi mengandung senyawa yang bersifat bioaktif yaitu: alkaloid, tanin, saponin, fenolik, triter penoid dan flavonoid. Senyawa ini berfungsi sebagai zat antifeedant dan repellent bagi hama sasaran dan sebagai antibakteri bagi kesehatan manusia [16]. Senyawa bioaktif tersebut 
diduga berfungsi sebagai penolak sehingga serangga dewasa enggan meletakkan telurnya.

Efektivitas anti peletakan telur sudah terlihat pada perlakuan 2,5 ekstrak daun mindi dengan penekanan peletakan telur sampai $72,0 \%$. Efektivitas antipeletakan telur tersebut meningkat dengan semakin meningkatnya konsentrasi ekstrak daun mindi yang diperlakukan. Antipeletakkan telur tertinggi dicapai pada perlakuan 7,5 dan $10 \%$ ekstrak daun mindi dengan antipeletakan telur mencapai 100,00 \%. Kemampuan ekstrak daun mindi dalam menekan peletakan telur serangga juga dilaporkan oleh Thakur dan Gupta (2013), perlakaun ekstrak daun mindi 3\% mampu menekan peletakan telur lalat buah Bactrocera spp. pada buat tomat dan cucurbitace sebesar $83,2 \%$. Selanjutnya [17] melaporkan, walaupun aplikasi ekstrak mindi tidak mempengaruhi jumlah telur kutu kebul Bemisia argentifolii yang diletakkan namun mampu menekan jumlah telur yang menetas. Aplikasi ekstrak mindi juga dilaporkan tidak berpengaruh terhadap kehidupan parasitoid Eretmocerus rui, sehingga dapat dipadukan dengan pengendalian secara hayati.

Peletakan telur oleh serangga betina dewasa merupakan proses interaksi antara serangga dan tanaman inang. Ada tidaknya senyawa kimia tertentu yang dapat menarik serangga dewasa untuk meletakkan telur merupakan faktor yang paling menentukan [18]; [19]. [20] menambahkan, peletakan telur oleh serangga betina dewasa berawal dari stimulus warna hijau dari daun tanaman inang, kemudian dilanjukan dengan rangsangan senyawa volatil maupun yang non volatil yang terkandung dalam tanaman inang. Tanaman Famili Brassisacea mengandung senyawa golongan glukosinolat [21]. Kelompok senyawa glukosinolat tersebut oleh [22] dianalisis sebagai glucobrassisin (komponen utama), kemudian beberapa komponen lainnya lainnya yaitu: glukoiberin, glukorapanin, sinigrin, dan neoglucobrassisin. Selanjutnya Halkier dan [23], melaporkan senyawa glukosinolat merupakan senyawa dengan kandungan sulfur tinggi, adanya enzim mirosinase mengurai senyawa glukosinolat menjadi isothiosianat, tiosianat dan nitril yang mempunyai efek bioaktif yang berbeda. Selanjutnya isotiosianat isothiosianat dapat dikenali oleh alat indera serangga hama kubis sehingga tertarik untuk meletakkan telur. Adanya perlakuan ekstrak daun mindi mampu mengacaukan komunikasi antara tanaman dan serangga sehingga stimulus yang dihasilkan daun kubis tidak dapat menarik imago betina $C$. pavonana untuk meletakkan telurnya.

\section{Uji kemempanan ekstrak daun mindi terhadap penetasan telur C. pavonana}

Jumlah kelompok telur yang diletakkan imago C. pavonana pada perlakuan konsentrasi daun mindi disajikan pada tabel 2. Persentase telur $C$. pavonana yang menetas bervariasi. Persentase telur menetas tertinggi terdapat pada perlakuan kontrol yaitu 88\%; sedangkan persentase telur menetas pada perlakuan ekstrak daun mindi pada berbagai konsentrasi lebih sedikit. Pada perlakuan ekstrak daun mindi persentase telur menetas semakin sedikit dengan meningkatnya konsentrasi ekstrak yang diperlakukan. Pada perlakuan ekstrak daun mindi 2,5\% mencapai 68,0 \% telur menetas dan semakin turun sampai pada perlakuan 10,0 \% persentase telur menetas mencapai 8,0 \% (Tabel 2). Hasil pengamatan menunjukkan kelompok telur yang diperlakukan dengan ekstrak daun mindi mengalami perubahan warna menjadi kekuningan, kemudian kecokelatan, dan pada akhirnya telur yang sudah mati tersebut ditumbuhi jamur saprofitik. Hal ini membuktikan bahwa ekstrak daun mindi mampu mempengaruhi embrio yang ada dalam telur sehingga tidak mampu berkembang lebih lanjut. Namun demikian, mekanisme daun mindi untuk dapat mematikan telur serangga masih belum diinformasikan, sehingga perlu diteliti lebih lanjut.

Tabel 2.

Persentase kelompok telur C. pavonana yang menetas pada perlakuan konsentrasi ekstrak daun mindi

\begin{tabular}{lcc}
\hline Perlakuan & $\begin{array}{c}\text { Kelompok telur } \\
\text { yang menetas (\%) }\end{array}$ & $\begin{array}{c}\text { Penekanan } \\
\text { penetasan } \\
\text { telur (\%) }\end{array}$ \\
\hline $\begin{array}{l}\text { Kontrol } \\
\text { Ekstrak daun mindi }\end{array}$ & $\begin{array}{c}88,0 \mathrm{~d} \\
68,0 \mathrm{~cd}\end{array}$ & - \\
$\begin{array}{l}2,5 \% \\
\text { Ekstrak daun mindi }\end{array}$ & $64,0 \mathrm{c}$ & 27,3 \\
$\begin{array}{l}5,0 \% \\
\text { Ekstrak daun mindi }\end{array}$ & $40,0 \mathrm{~b}$ & 54,5 \\
$\begin{array}{l}7,5 \% \\
\text { Ekstrak daun mindi } \\
10,0 \%\end{array}$ & 8,0 a & 90,9 \\
\hline
\end{tabular}

Keterangan: Angka dalam kolom yang sama yang diikuti huruf kecil sama tidak berbeda nyata menurut DMRT 5\%.

Hasil analisis statistik menunjukkan bahwa semua perlakuan ekstrak daun mindi berpengaruh nyata terhadap persentase telur menetas dibandingkan dengan perlakuan kontrol. Hal ini membuktikan ekstrak daun mindimempunyai efek anti penetasan telur C. pavonana. Efektivitas anti penetasan telur sudah terlihat pada perlakuan 5,0 ekstrak daun indi dengan penekanan peletakan telur sampai $27,3 \%$. Efektivitas anti penetasan telur tersebut meningkat tajam dengan semakin meningkatnya konsentrasi ekstrak daun mindi yang diperlakukan. Pada perlakuan 7,5 \% ekstrak daun mindi antipenetasan mencapai 54,55\%. 
Sedangkan antipenetasan telur tertinggi dicapai pada perlakuan $10 \%$ ekstrak daun mindi dengan anti penetasan telur mencapai 90,9\%. Senyawa bioaktif yang dikandung ekstrak daun mindi diduga mampu mempengaruhi ebrio dalam telur sehingga tidak berkembang lebih lanjut.

Azadirachtin merupakan senyawa bioaktif utama yang terkandung dalam tanaman Famili Meliaceae termasuk didalamnya tanaman mindi. Senyawa ini beserta komponen lainnya mampu mempengaruhi pertumbuhan dan perkembangan serangga melalui beberapa mekanisme [24]. Kemampuan azadirachtin sebagai ovisida dilaporkan beberapa peneliti dengan hasil yang bervariasi. [25], melaporkan bahwa perlakuan azadirachtin dengan metode dipping mampu menekan penetasan telur Earias vittella secara nyata. Selanjutnya [26] malaporkan, azadractin $2 \%$ mampu menekan penetasan telur Earias vittella sampai $95,82 \%$. Hasil penelitian yang beragam ini diduga disebabkan perbedaan morfologi dan fisiologi dari telur serangga uji.

\section{SIMPULAN}

1. Ekstrak daun mindi konsentrasi $7-10 \%$ mampu menekan $100 \%$ peletakan telur imago betina $C$. pavonana

2. Ekstrak daun mindi konsentrasi 10\% mampu menekan 90,9\% penetasan telur C. pavonana

\section{DAFTAR RUJUKAN}

[1] Higdon, J.V, Delage, B., Williams, D.E. and Dashwood, R.H. 2007. Cruciferous vegetables and human cancer risk: epidemiologic evidence and mechanistic basis. Pharmacol Res. 55(3):224-36.

[2] Keck A.S, and Finley, J.W. 2004. Cruciferous vegetables: cancer protective mechanisms of glucosinolate hydrolysis products and selenium. Integr Cancer Ther. 3(1):5-12.

[3] Rokayya, S., Li, C.J., Zhao, Y., Li, Y., and Sun, C.H. 2013. Cababge (Brassica oleracea var. Capitata) Phytochemichals with antioxidant and anti-inflamatory potential. Asian Pasific Jurnal of Cancer Prevention 14(11):6657-6662, DOI:http://dx.doi.org/10.7314/APJCP.2013.14.11.6657.

[4] Tjitaresmi, A., Kusuma, S.A.F., dan D. Rusmiati, 2017. Cabbage leaf extract (Brassca oleracea var. capitata) as a herbal medicine for leukorrheal. Asian Journal of Pharmaceutichal and Clinical Research Special Isue (May):38-40.

DOI:http://dx.doi.org/110.22159/ajpcr.2017.v10s2.19483.

[5] BPS, 2017. Produksi Tanaman sayuran , https://www.bps.go.id/site/resultTab, diakses 1 September 2017.

[6] Paat, F.J., Palealu, J. dan Manueke, J. 2012. Produksi kubis dan presentasi serangan Crocidolomia pavonana pada beberapa pola tanam kubis. Eugenia 18(1):72-80.
[7] Dhandapani, N., Shelkar, U.R., and Murugan, M. 2003. Bio-Intensive Pest Management (BIPM) in major vegetable crops: an Indian prespective. Food, Agriculture \& Environment, 1(2):333-339.

[8] Sastrosiswojo, S., Uhan, T.S., Sutarya, R. 2005. Penerapan Teknologi PHT pada Tanaman kubis. Monografi No. 21. ISBN: 979- 8403- 35- 7. Balai Penelitian Tanaman Sayuran, Pusat Penelitian dan Pengembangan Hortikultura, Badan Penelitian dan Pengembangan Pertanian.

[9] Vasquez, D.L.L, Sabado, E.M., and Bangi, J.C. 2016. Insect pest of red cababage (Brassica oleracea L.) and life cycle of the cabbage worm, Crocidolomia pavonana F. In Lanalo del Sur Province Philipine. Philipine Entomology 30(2):149-158.

[10] Isman, M.B., 2006. Botanical insecticides, deterrent and repellent in modern agriculture and an increasingly regulated word. Annual Review of Entomology51:45-66.

[11] Sharma, D. and Paul, Y. 2013. Preliminary and Pharmacological Profile of Melia azedarach L. An Overview. Journal of Applied Pharmaceutical Science 3(12):133-138.

[12] Bullangpoti, Wajnberg V.E., Audant P., and Feyereisen, R. 2012. Antifeedant activity of Jatropha gossypifolia and Melia azedarach senescent leaf extracts on Spodoptera frugiperda (Lepidoptera: Noctuidae) and their potential use as synergists. Pest Management Science 68(9):12551264, https://doi.org/10.1002/ps.3291

[13] Carpinella, M.C., Defago, M.T., Valladares, G., and Palacios, S.M. 2003. Antifeedant and Insecticide Properties of a Limonoid from Melia azedarach (Meliaceae) with Potential Use for Pest Management. $J$. Agric. Food Chem.51 (2):369-374, DOI: 10.1021/jfo25811w.

[14] Nathan S.S., and Sehoon, K. 2006. Effects of Melia azedarach L. extract on the teak defoliator Hyblaea puera Cramer (Lepidoptera: Hyblaeidae). Crop Protecton 25(3):287-291, https://doi.org/10.1016/j.cropro.2005.03.023

[15] Ahmed, M.F., Rao, A.S., Ahemad, S.R., and Ibrahim, M. 2012. Phytochemical Studies and Antioxidant Activity of Melia azedarach Linn Leaves by Dpph Scavenging Assay. International Journal of Pharmaceutical Applications 3(1) : 271-276

[16] Asadujjaman, M., Saed, A., Hossain, M.A., and Karmakar, U.K. 2013. Assessment of bioactivities of ethanolic extract of Melia azedarach (Meliaceae) leaves. Journal of Coastal Life Medicine1(2) : 118-122

[17] Hammad, E.A. and Mcauslane, H.J. 2006. Effect of Melia azedarach L. Extract on Bemisia argentifolii (Hemiptera: Aleyrodidae) and Its Biocontrol Agent Eretmocerus rui (Hymenoptera: Aphelinidae). Entomological Society of America 35(3):740-745.

[18] Bukovinszky, T., Potting R.P.J., Clough Y., van Lenteren, J.C. and Vet, L.E.M. 2005. The role of pre- and postalighting detection mechanisms in the responses to patch size by specialist herbivores. Oikos, 109: 435-446.

[19] Najmeh E., Talebi, A.A., Fathipour, Y. and Zamani, A.A. 2008. Host Plants Effect on Preference, Development and Reproduction of Plutella xylostella (L.) (Lepidoptera: Plutellidae) Under Laboratory Conditions. Advances in Environmental Biology, 2(3): 108-114.

[20]Finch, S., and Collier R.H. 200o. Host-plant selection by insects-a theory based on 'appropriate/inappropriate 
landings' by pest insects of cruciferous plant. Entomologia Experimentalis et Applicata 96: 91-102.

[21] Huang, X., Renwick, J.A.A., and Gupta, K.S. 1993. Oviposition stimulants and deterrents regulating differential acceptance of Iberis amara by Pieris rapae and P. napi oleracea. Journal of Chemical Ecology 19: 1645-1662.

[22] Sarıkamı G., Balkaya, A.,and Yanmaz, R. 2009. Glucosinolates within a collection of white head cabbages (Brassica oleracea var. capitata sub.var. alba) from Turkey. African Journal of Biotechnology 8 (19): 50465052.

[23] Halkier, B.A. and Gershenzon ,J. 2006. Biology and Biochemistry of Glucosinolate. Annual Review of Plant Biology 57(1): 303-330.

[24] Mulia, M.S., and Su, E.T. 1999. Activity and biological effects against arthropods of medical and veterinary importance. Journal of the American Mosquito Control Association' 15(2):133-152,

[25] Gajmer, T., Singh, R., Saini, R.K., and Kalidhar S.B. 2002. Effect of methanolic extracts of neem (Azadirachta indica A. Juss) and bakain (Melia azedarach L) seeds on oviposition and egg hatching of Earias vittella (Fab.) (Lep., Noctuidae), Journal of apllied entomology 126(5): 238243, https://doi.org/10.1046/j.1439-0418.2002.00649.x

[26] Thara, S., Kingsley, S., and Revathi, N. 2008. Evaluation of neem derivatives as ovicides against Earias vittella (Lepidoptera: Noctuidae), Journal of Applied Zoological Researches 19(1):54-56 